\title{
当教室に扣ける下咽頭頸部食道癌の治療成績
}

\author{
秋定 健・山本 英一*·佐藤 幸弘 \\ 半田 徹 ・ 折田 洋造

\section{Results of Treatment of Carcinoma of the Hypopharynx and Cervical Esophagus}

\author{
Takeshi Akisada, Yukihiro Sato, Toru Handa and Yozo Orita \\ (Kawasaki Medical School) \\ Hidekazu Yamamoto \\ (Kawasaki Hospital, Kawasaki Medical School)
}

\begin{abstract}
A retrospective analysis was made of 40 cases of carcinoma of the hypopharynx and cervical esophagus treated between 1974 and 1992. Twenty-two lesions occurred in the piriform sinus, four in the postcricoid, five in the posterior wall, seven in the cervical esophagus and two were of unknown origin. Of the total, $55.3 \%$ were $\mathrm{T}_{3}$ or $\mathrm{T}_{4}$, and the rate of cervical lymph node metastasis was $52.6 \%$. Of the total, $76.3 \%$ were Stage $\mathbb{I I}$ or $\mathbb{N}$. The initial treatment methods applied in 38 cases were: irradiation including chemotherapy in 30 cases, surgery in seven cases, and no treatment in one case. Surgery for the local carcinomas including three recurrent cases consisted of pharyngolaryngectomy in four and pharyngolaryngoesophagectomy in six. Two-year and five-year survival rates for all patients were $36.8 \%$ and $14.8 \%$, respectively.

There were no significant differences in the two-year survival rates between the surgery group and the radiation group.
\end{abstract}

Key words: carcinoma of the hypopharynx and cervical esophagus, cervical lymph node metastasis, chemotherapy, irradiation, surgery

はじめに

下咽頭頸部食道癌は頭頸部腫瘍のなかでも極 めて予後が悪く, 5 年生存率は $40 \%$ 以下である. 治療は化学療法, 放射線, 手術を組み合わせて 行なわれて扣り, 最近は化学療法も発達し, 再 建手術の発達により広範囲の摘出も可能となっ てきた。しかし未だに治療成績の向上はかなり
困難となっている．今回当教室開設以来 18 年間 の本疾患について検討したので若干の考察を加 えて報告する。

\section{対象}

昭和 49 年 3 月から平成 4 年 3 月までに当科を 受診し, 入院治療した下咽頭頸部食道癌 40 例に ついて統計的観察を行なった。 


\section{結果}

（1）性別，年路別，発生部位

性別では男性29例, 女性11例と男性に多く, 初診時年齢は42歳から92歳までで，平均63.6歳 であった５0，60歳代がいずれも12例と多く全 体の60\%を占めていた(図 1 ).

発生部位は梨状陷凹 22 例, 輪状軟骨後部 4 例, 咽頭後壁 5 例, 頸部食道 7 例, 不明 2 例であっ た. 梨状陥凹男: 女 $=9: 2$ と男性に多く, 咽 頭後壁は男 : 女 $=3: 2$, 頸部食道は男 : 女 $=3$ : 4 とやや女性に多い傾向が認められたが，一般 的に女性優位と報告される輪状軟骨後部は男 : 女 $=3: 1$ と男性に多かった(図 2). 病理組織

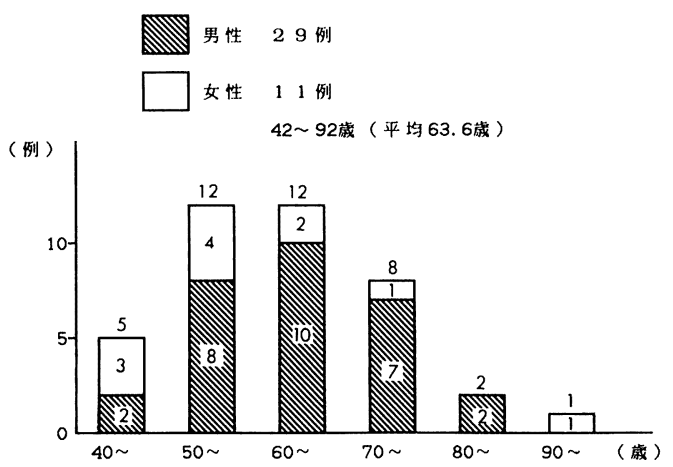

図 1 下咽頭頸部食道癌 40 例の性・年㱓分布

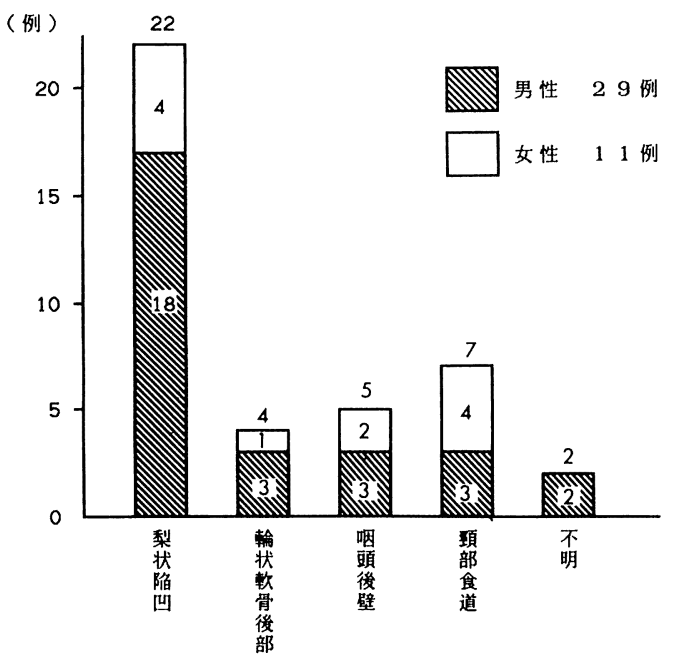

図 2 発生部位と性別
は全例扁平上皮癌であった。

（2）腫瘍の進展度，転移

発生部位のはっきりした38例で腫瘍の拡がり， リンパ節転移，遠隔転移などについて検討した。 下咽頭癌, 頸部食道癌共に TNM 分類はそれ以 前の症例も1978年の UICC 分類に従って行な った.

(a) 原発巣

TNM 分類を用いた原発巣の進展度は $\mathrm{T} 1$ ： 9 例, T2: 8 例, T3 $: 14$ 例, T4 $: 7$ 例と T3, $\mathrm{T} 4$ の進展例が38例中 21 例 $(55.3 \%)$ を占めてお り, 特に梨状陥凹原発例で進展例が22例中15例

表 1 TNM 分類

\begin{tabular}{c|rccc|r}
\hline \hline & $\mathrm{N}_{0}$ & $\mathrm{~N}_{1}$ & $\mathrm{~N}_{2}$ & $\mathrm{~N}_{3}$ & 計 \\
\hline $\mathrm{T}_{1}$ & 4 & 2 & 2 & 1 & 9 \\
$\mathrm{~T}_{2}$ & 4 & & 1 & 3 & 8 \\
$\mathrm{~T}_{3}$ & 7 & 1 & 2 & 4 & 14 \\
$\mathrm{~T}_{4}$ & 3 & 1 & & 3 & 7 \\
\hline 計 & 18 & 4 & 5 & 11 & 38
\end{tabular}

表 2 TNM 分類（発生部位別）

\begin{tabular}{|c|c|c|c|c|c|c|}
\hline & & $\mathrm{N}_{0}$ & $\mathrm{~N}_{1}$ & $\mathrm{~N}_{2}$ & $\mathrm{~N}_{3}$ & 計 \\
\hline \multirow{4}{*}{ 梨状陥凹 } & $\mathrm{T}_{1}$ & 3 & & & & 3 \\
\hline & $\mathrm{T}_{2}$ & 2 & & & 2 & 4 \\
\hline & $\mathrm{T}_{3}$ & 5 & 1 & 1 & 3 & 10 \\
\hline & $\mathrm{T}_{4}$ & 1 & 1 & & 3 & 5 \\
\hline \multirow{3}{*}{ 輪状軟骨後部 } & $\mathrm{T}_{1}$ & & 1 & 1 & & 2 \\
\hline & $\mathrm{T}_{2}$ & & & & & \\
\hline & $\mathrm{T}_{4}$ & 2 & & & & 2 \\
\hline \multirow{4}{*}{ 咽頭後壁 } & $\mathrm{T}_{1}$ & 1 & 1 & & & 2 \\
\hline & $\mathrm{T}_{2}$ & 1 & & 1 & & 2 \\
\hline & $\mathrm{T}_{3}$ & 1 & & & & 1 \\
\hline & $\mathrm{T}_{4}$ & & & & & \\
\hline \multirow{3}{*}{ 頸部食道 } & $\mathrm{T}_{1}$ & & & 1 & 1 & 2 \\
\hline & $\mathrm{T}_{2}$ & 1 & & & 1 & 2 \\
\hline & $\mathrm{T}_{3}$ & 1 & & 1 & 1 & 3 \\
\hline \multicolumn{2}{|l|}{ 計 } & 18 & 4 & 5 & 11 & 38 \\
\hline
\end{tabular}


と多かった(表 1，2）.

（b）頸部リンパ節転移

頸部にリンパ節転移を認めたものは38例中 20 例(52.6\%)であり,その内訳は N1：4 例, N2： 5 例，N3：11例であった。原発部位別には， 梨状陥凹では22例中11例(50\%)に転移を認め， 特に N3 が 8 例と高率であった．輪状軟骨後部 では 4 例中 2 例 $(50 \%)$ に転移を認めた。咽頭後 壁では 5 例中 2 例 $(40 \%)$ に転移を認めた。頸部

表 3 STAGE 分類

\begin{tabular}{l|rrrr|r}
\hline \hline & I & II & III & N & 計 \\
\hline 梨状陷凹 & 3 & 2 & 6 & 11 & 22 \\
輪状軟骨後部 & & & 1 & 3 & 4 \\
咽頭後壁 & 1 & 1 & 2 & 1 & 5 \\
頸部食道 & & 2 & 5 & & 7 \\
\hline \multicolumn{1}{c|}{ 計 } & 4 & 5 & 14 & 15 & 38
\end{tabular}

食道では 7 例中 5 例 $(71.4 \%)$ と高率に転移を認 め, 特に N3 が 3 例と高率であった(表 1，2）.

（c）遠隔転移

遠隔転移は 3 例に認め, 全例肺転移であった。 (d) 病期分類

病期分類では I 期 4 例，III期 5 例，III期14例, $\mathrm{IV}$ 期15例と 29 例 (76.3\%) が III, $\mathrm{N}$ 期の進行癌で あった。 原発部位別では, 梨状陥凹が22例中 17 例 $(77.3 \%)$, 輪状軟骨後部が 4 例中 4 例 (100 $\%)$, 咽頭後壁が 5 例中 3 例 (60\%), 頸部食道 が 7 例中 5 例 $(71.4 \%)$ が進行癌で特に部位別の 差は認めなかった(表 3 ).

（3）治療成績

一次治療は放射線治療単独 5 例, 化学療法十 放射線治療 25 例, 化学療法+手術 1 例, 化学療 法十放射線治療＋手術 6 例で，化学療法十放射 線治療の再発 3 例に対し手術を施行した(表 4 ). 手術は咽喉摘が 4 例, 咽喉食摘が 6 例で, 頸

表 4 原発巣の拡がりと治療法 [( ）は 2 年生存率 $]$

\begin{tabular}{|c|c|c|c|c|c|c|}
\hline T分類 & 放射線 & $\begin{array}{l}\text { 华学療法 } \\
\text { 放射線 }\end{array}$ & $\begin{array}{c}\text { 化学療法 } \\
\text { 手 術 }\end{array}$ & $\begin{array}{c}\text { 华学療法 } \\
\text { 放 射 線 } \\
\text { 再発後手術 }\end{array}$ & $\begin{array}{c}\text { 化学療法 } \\
\text { 手術 } \\
\text { 放 射 線 }\end{array}$ & 治療 $(-)$ \\
\hline $\mathrm{T}_{1}$ & 0 & $\begin{array}{c}5 \\
(40.0 \%)\end{array}$ & 0 & $(100.0 \%)$ & $\begin{array}{l}2 \\
(0 \%)\end{array}$ & 0 \\
\hline $\mathrm{T}_{2}$ & $\begin{array}{c}1 \\
(100.0 \%)\end{array}$ & $\begin{array}{l}6 \\
(0 \%)\end{array}$ & $\begin{array}{c}1 \\
(0 \%)\end{array}$ & 0 & 0 & 0 \\
\hline $\mathrm{T}_{3}$ & $\begin{array}{l}3 \\
(0 \%) \\
\end{array}$ & $\begin{array}{c}7 \\
(28.6 \%) \\
\end{array}$ & 0 & 0 & $\begin{array}{c}3 \\
(66.7 \%) \\
\end{array}$ & $\begin{array}{c}1 \\
(100.0 \%) \\
\end{array}$ \\
\hline $\mathrm{T}_{4}$ & $\begin{array}{c}1 \\
(100.0 \%)\end{array}$ & $\begin{array}{c}4 \\
(25.0 \%)\end{array}$ & 0 & $1(0 \%)$ & $\frac{1}{(0 \%)}$ & 0 \\
\hline 計 & $\begin{array}{c}5 \\
(40.0 \%)\end{array}$ & $\begin{array}{c}22 \\
(25.9 \%)\end{array}$ & $\begin{array}{c}1 \\
(0 \%)\end{array}$ & $\begin{array}{c}3 \\
(66.7 \%)\end{array}$ & $\begin{array}{c}6 \\
(66.7 \%)\end{array}$ & $\begin{array}{c}1 \\
(100.0 \%)\end{array}$ \\
\hline
\end{tabular}

表 5 原発巣に対する手術的治療

\begin{tabular}{l|c|l|c}
\hline \hline & 症例数 & \multicolumn{1}{|c|}{ 再 建 法 } & 局所再発 \\
\hline 咽喉頭摘出 & 4 & $\begin{array}{l}\text { DP 皮弁 2 } \\
\text { 再建不能 2 (2 次的形成咽頭閉鎖) }\end{array}$ & 4 \\
\hline 咽喉頭食道摘出 & 6 & $\begin{array}{l}\text { 前腕皮弁 } \\
\text { 大腿外側皮弁 }\end{array}$ & 2 \\
胃 管 & 3 & 2
\end{tabular}


部郭清は患側のみが 3 例, 両側共が 6 例に施行 した，再建は DP 皮弁 2 例，胃管 3 例，遊離前 腕皮弁 1 例，遊離大腿外側皮弁 2 例であった (表 5 ).

治療成績は現在生存例が 5 例, 死亡例が33例 で，全体の生存率 (Kaplan-Meier 法) は 2 年生 存率が $36.8 \%, 5$ 年生存率が $14.8 \%$ と低率であ った. $\mathrm{T} 1$ 症例では 2 年生存率が $66.7 \%, 5$ 年 生存率が $44.4 \%$ と高率であったが，T2 以上の 症例ではいずれも 2 年生存率 $30 \%$ 以下， 5 年生 存率15\%以下と低率であった. N分類ではいず れも 2 年生存率 $25 \%$ ～ $50 \% ， 5$ 年生存率 $0 \%$ 20\%で明らかな差を認めなかった（表 6，7）.

原発部位別では梨状陥凹, 咽頭後壁でやや生 存率が高く, 輪状軟骨後部, 頸部食道で低率で あった(表 7 ).

治療法別の 2 年生存率の検討では, 有意差は 認められず，手術の有無でも差は認められなか った(表 4).

手術法による再発率の比較では，咽喉摘が 4 例中 4 例 $(100 \%)$, 咽喉食摘が 6 例中 2 例 (33.3 \%)であった(表 5 ).

頸部郭清の有無では, 両側施行例で 2 年生存

表 6 TNM 分類生存率（Kaplan-Meier 法）

\begin{tabular}{|c|c|c|c|c|c|}
\hline & 2 年 & 5 年 & & 2 年 & 5 年 \\
\hline $\mathrm{T}_{1}$ & $66.7 \%$ & $44.4 \%$ & $\mathrm{~N}_{0}$ & $33.3 \%$ & $20.0 \%$ \\
\hline $\mathrm{T}_{2}$ & $25.0 \%$ & $0 \%$ & $\mathrm{~N}_{1}$ & $50.0 \%$ & $0 \%$ \\
\hline $\mathrm{T}_{3}$ & $28.6 \%$ & $7.1 \%$ & $\mathrm{~N}_{2}$ & $40.0 \%$ & $20.0 \%$ \\
\hline $\mathrm{T}_{4}$ & $28.6 \%$ & $14.3 \%$ & $\mathrm{~N}_{3}$ & $27.3 \%$ & $18.2 \%$ \\
\hline
\end{tabular}

表 7 発生部位別生存率（Kaplan-Meier 法）

\begin{tabular}{c|c|r}
\hline \hline & 2 年 & \multicolumn{1}{|c}{5 年 } \\
\hline 梨状陥凹 & $45.5 \%$ & $16.4 \%$ \\
輪状軟骨後部 & $25.0 \%$ & $0 \%$ \\
咽頭後壁 & $40.0 \%$ & $20.0 \%$ \\
頸部食道 & $14.3 \%$ & $14.3 \%$ \\
\hline 全 体 & $36.8 \%$ & $14.8 \%$
\end{tabular}

率が良好であった(表 8 )。

5 年以上生存例の内訳は化学療法十放射線治 療の 5 例で，その内 2 例は再発に対して手術を 施行している.

死亡例は原病死が22例で，その内訳は局所再 発が10例, 頸部再発が 4 例, 出血が 4 例, 遠隔 転移が 4 例で, 肺線維症の 5 例を含めて他病死 が 9 例で，不明が 2 例であった(表 9 ).

\section{考按}

下咽頭頸部食道癌は診断治療上多くの問題点 を抱えているが，特に頭頸部癌のなかでも非常 に発見が遅いために病期 III, $\mathrm{N}$ の進行癌が多い ことと, 早期に頸部リンパ節転移を来し，その 処理に難泳することが予後の悪い 2 大要因と考 兄れる。この問題の克服のために様々な工夫 が成されているが，依然として 5 年生存率は30 \%前後にとどまっているのが現状である．今回

表 8 頸部リンパ節転移に対する治療

[（）は 2 年生存率 $]$

\begin{tabular}{c|c|c|c}
\hline \hline & 非手術例 & 手術例 (一側) & 手術例 (両側) \\
\hline $\mathrm{N}_{0}$ & $\begin{array}{c}14 \\
(32.6 \%)\end{array}$ & $\begin{array}{c}2 \\
(50.0 \%)\end{array}$ & $\begin{array}{c}2 \\
(50.0 \%)\end{array}$ \\
\hline $\mathrm{N}_{1}$ & $\begin{array}{c}2 \\
(50.0 \%)\end{array}$ & $\begin{array}{c}1 \\
(0 \%)\end{array}$ & $\begin{array}{c}1 \\
(100.0 \%)\end{array}$ \\
\hline $\mathrm{N}_{2}$ & $\begin{array}{c}3 \\
(0 \%)\end{array}$ & 0 & $\begin{array}{c}3 \\
(66.7 \%)\end{array}$ \\
\hline $\mathrm{N}_{3}$ & $\begin{array}{c}10 \\
(30.0 \%)\end{array}$ & 0 & 0 \\
\hline 計 & $\begin{array}{c}29 \\
(30.1 \%)\end{array}$ & $\begin{array}{c}3 \\
(33.3 \%)\end{array}$ & $\begin{array}{c}6 \\
(66.7 \%)\end{array}$
\end{tabular}

表 9 死因の検討

\begin{tabular}{cc}
\hline \hline 局所再発 & 10 例 \\
頸部再発 & 4 例 \\
出 血 & 4 例 \\
遠隔転移 & 4 例 \\
肺線維症 & 5 例 \\
他病死 & 4 例 \\
不 明 & 2 例 \\
\hline 計 & 33 例
\end{tabular}


の我々の統計では 5 年生存率 $14.8 \%$ と極めて低 率であり，その原因を探るべく各項目別に検討 を加えてみた。

\section{1) 性 別}

性別については諸家の報告で様々であり，平 野ら1)は男性26例，女性20例，天津ら2)は男性 87 例，女性51例，佐藤3 ${ }^{3}$ は男性 144 例，女性93 例，また田頭ら4) は男性19例，女性12例とかな り女性にも多い報告をしているが，戸田ら5) は 男性29例, 女性 5 例, 松井ら ${ }^{6)}$ は男性59例, 女 性12例と女性に少ない報告もあり，当科の統計 は佐藤ら ${ }^{7)}$ の男性31例，女性17例と同様中間的 な結果となっている。これらは，女性に多い輪 状軟骨後部原発型の頻度と, その男女差に左右 されていると思われる．また性別での予後判定 は成されていないが，生存率への影響は少ない と思われる。

\section{2）年 齢}

他施設の統計をみると，戸田ら ${ }^{5)}$ は50〜 60歳 代に多く, 平均65歳で, 田頭ら ${ }^{4)}$ は60歳代に多 く, 次いで50歳代と報告し, 佐藤ら7) は60歳代 に多く，次いで50歳代，また松井ら6)は60歳代 に次いで70歳代と報告している．いずれも60歳 代に多く，次いで50歳代か70歳代で，平均は60 歳〜65歳であり，今回の統計も同様で特に高年 龄層に偏っているわけではない，しかし宮原8) が述べているように，最近高齢者の増加が他の 癌と同様著しく，今後 QOL を考虑した治療が 望まれる。

3 ) 発生部位

あまり統計に加えていない頸部食道を除いて， ほとんどの報告で梨状陷凹原発が最も多く，次 いで輪状軟骨後部，咽頭後壁の順で，今回も咽 頭後壁がやや多いものの注涪同様の結果と思わ れる. 発生部位別の生存率は天津ら ${ }^{2)}$, 松井 ら゙)はほとんど差がないとしているが，田中 $5^{9)}$ や小野ら 10) の統計では梨状陥凹原発が良 く, 輪状軟骨後部, 咽頭後壁が悪く, 田頭ら ${ }^{4)}$ は同様の報告をし，その原因を輪状軟骨後部で stage の高い症例が多いことであるとしており，
当科の統計でも全例 stage III, $\mathrm{N}$ の輪状軟骨後 部の生存率が悪い。これらのことから発生部位 別にはあまり生存率には影響はなく，その進行 度に左右されている可能性が示唆される。

4 ）原発巣の進展度执よび治療

TNM 分類での原発巣の進展度 $(\mathrm{T})$ は，発見 が遅いことを反映して，いずれの報告も T3 以 上の進行癌が $50 \%$ から $70 \%$ の高率であり，当科 の $55.3 \%$ は決して高いとはいえない。またT分 類別の生存率は佐藤ら ${ }^{7)}$ が検討して扣り，T2 の実測 5 年生存率が $50 \%$ で，T3 以上が $37.5 \%$ と差が認められ，田中ら9)の統計でも T分類が 進めば生存率が悪化している。しかし吉野ら ${ }^{11)}$ はT分類別には有意差がなく， N 分類が予後決 定因子としている．今回 $\mathrm{T} 1$ のみ 5 年生存率が 良好で T2，T3，T4 は極めて低率であるが，こ れは $\mathrm{T} 1$ で意外に手術例が多く，本来手術を先 行すべき $\mathrm{T} 2$ 以上の症例で注とんど保存的治療 となっているためと思われた，原発巣に対する 治療は，手術例がいずれも併用で，再発に対す る手術例を加えても38例中10例と他の報告に比 べ著しく少ない，佐藤ら ${ }^{3)}$ は162例中，放射線 単独が 60 例で 5 年生存率 $9 \%$ に対し, 手術単独 が 64 例で 5 生率36\%，照射执よび手術が38例で 5 生率 $50 \%$ と高率と報告し, 戸田ら5) 女手術例 が有意に生存率が高いと報告している．最近の 頭頸部再建術の進歩から，当施設に挆いては今 後手術適応範囲を拡げて積極的に手術を施行し， 咽喉摘に扣ける再発の多さから考光ても，その 切除範囲を，田中ら ${ }^{9)}$ が報告した咽頭側 $20 \mathrm{~mm}$, 食道側 $25 \mathrm{~mm}$ などのように大きく設定すべき と思われる。また放射線治療の併用についても 術前照射か術後照射が良いか一定の見解がなく， 最近田中ら ${ }^{9)}$ は照射の有無, 時期でも差がない と報告して扣り, 決定的な単独あるいは併用治 療はないといわざるを得ない。

5 ）頸部リンパ節転移および治療

下咽頭癌の治療に掞いて最も問題となる頸部 リンパ節転移の有無については，いずれの報告 も N1 以上の転移ありが50\%〜 60\%以上の高率 
に認められ，今回と同様であった。治療成績に ついては, 佐藤ら7) と戸田ら5) は N0 と N1 以 上で生存率に差を認めており, 戸田ら5) は患側 の予防的郭清は必要だが，健側は経過観察をす ればあえて予防的郭清をする必要はないとして おり，平野ら1）同様の報告をしているが，予 防的郭清をする場合は徹底的にすることを強調 している. 佐藤ら ${ }^{7)}$ も N0 に対する患側の予防 的郭清の重要性について述べている. また天津 ら 2) $\mathrm{N}+$ 症例では根治的頸部郭清術に加えて 傍気管リンパ節の郭清や甲状腺の摘出を行なら としている. それに対して田頭ら ${ }^{4)} \mathrm{N} 1$ 症例 のほとんどが放射線扣よび化学療法で制御でき て扣り，治療方針としてN1，N2 は化学療法と 放射線療法, N3 は手術を選択している. 今回 の統計では $\mathrm{N} 0$ 症例に対する予防的郭清は18例 中 4 例 $(22.2 \%)$ と少なく, 手術例が 2 年生存率 は良好であることと， N +症例に対する頸部郭 清は20例中 5 例 (25\%)で特に N3 の10例はいず れも保存的治療として扣り, 手術例が生存率が 良好である。当科に打ける低い生存率の原因と して, 原発巣に対する手術例が少ないことと共 に, 頸部郭清症例が他の報告と比較して極端に 少ないことが考えられる. 最近吉野ら ${ }^{11)}$ が頸 部郭清を徹底することで再発率が減少したと報 告しており, 今後 $\mathrm{N}+$ 症例に対する積極的な頸 部郭清と, N0 症例に対しても予防的郭清を考 慮した治療が望まれる。

\section{6 ）遠隔転移}

下咽頭癌では肺や骨への遠隔転移が比較的多 く, それらの発見が重要となってくる，その頻

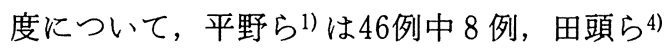
は31例中 4 例と報告しており，今回も38例中 3 例でほぼ同様の結果と思われる. 宮原ら ${ }^{12)}$ は 早期の遠隔転移や重複癌の発見のため, 胸部 $\mathrm{x}$ 線撮影の他, 食道・胃 - 十二指腸造影や腹部工 コー, RI 検査もルーチンに行ならとしている. しかし遠隔転移を来すと化学療法で延命をはか るしかないため, 予防として手術前の neo-adjuvant-chemotherapy を施行するなどが必要と
思われる. 最近当科では超選択的に動注化学療 法を施行し，良好な成績を治めて括り，今後の 予後向上に期待が持たれる.

$$
\text { まとめ }
$$

当教室で昭和 49 年 3 月から平成 4 年 3 月まで の18年間に治療を行なった下咽頭頸部食道癌 40 例について検討した.

1. 男性29例, 女性11例で50歳代，60歳代に 多く, 発生部位は梨状陷凹 22 例, 輪状軟骨後部 4 例, 咽頭後壁 5 例, 頸部食道 7 例, 不明 2 例 であった。

2. T3，T4 の進展例が21例 (55.3\%)で $\mathrm{N}+$ 症例は20例(52.6\%)で遠隔転移は 3 例に認めた。 stage III, N の進行癌が29例(76.3\%)であった.

3. 治療は化学療法, 放射線, 手術の単独ま たは組み合わせで行なったが，化学療法と放射 線の組み合わせが 25 例と多く, 治療法別の生存 率の差は認められなかった。

4. 手術は咽喉摘が 4 例, 咽喉食摘が 6 例で 頸部郭清は 9 例に施行した. 再建は DP 皮弁, 胃管，前腕皮弁，大腿外側皮弁などを使用した。

5 . 全体の 2 年生存率は $36.8 \%$ で， 5 年生存 率は14.8\% と低率であった。死因は局所再発が 10例と最多であった。

6. 動注化学療法を含めた neo-adjuvantchemotherapy と積極的な手術の必要性につい て述べた.

本論文の要旨は, 第92回日本耳鼻咽喉科学会総会 (平成 3 年 5 月 18 日, 福岡)にてロ演した.

\section{参考文献}

1）平野実, 進 武幹, 三橋重信, 他: 教室にお ける下咽頭頸部食道癌の遠隔成績. 耳鼻 22 : 737 747, 1976.

2) 天津睦朗, 松居敏夫, 牧 孝, 他: 下咽頭頸 部食道癌の治療法とその成績 一手術的治療を 中心として一. 耳鼻臨床 $75: 641 \sim 650,1982$.

3）佐藤武男：下咽頭・頸部食道癌の治療. 日気食 会報 $23: 130 \sim 138,1972$.

4）田頭宣治, 渡部雄二, 小村 良, 他: 当教室に 扣ける下咽頭癌の遠隔成績. 耳鼻臨床 補 27 ： 
212 217, 1988.

5）戸田勝也, 小笠原寛, 兵 典子, 他 : 教室に抒 ける下咽頭癌の治療成績. 耳鼻臨床 補 $4: 47$ 52, 1986.

6）松井正典, 神宮賢一, 早㴊尚文, 他：下咽頭癌 の治療成績. 放治システム 研究 $2: 77 \sim 82$, 1985.

7）佐藤文彦, 斎藤 等, 斎藤 章, 他 : 下咽頭頸 部食道癌治療成績の推移. 日気食会報 $34: 331$ $\sim 336,1983$.

8）宮原 裕 : 下咽頭癌の疫学と Quality of Life を 考慮した治療. 日気食会報 42：121～126，1991.

9）田中信三, 平野 実, 松岡秀隆, 他 : 下咽頭癌 の治療 -20 年間 173 例の検討一. 日気食会報
$43: 88 \sim 95,1992$.

10）小野 勇, 海老原敏, 斉藤裕夫, 他: 下咽頭頸 部食道癌, 遠隔成績よりみた治療方針の検討. 癌の臨床 $26: 1169 \sim 1173,1980$.

11）吉野邦俊, 佐藤武男, 馬谷克則, 他: 下咽頭癌 の治療. 日気食会報 $43: 81 \sim 87,1992$.

12）宮原 裕, 鶴田至裕, 馬谷克則, 他: 下咽頭 頸部食道癌の実態と治療 (第 2 報) 日気食会報 $37: 437 \sim 445,1986$.

$$
\left(\begin{array}{l}
\text { 別刷請求先 : 秋定 健 } \\
\mathbf{T} 701-01 \text { 倉敷市松島 } 577 \\
\text { 川崎医科大学耳鼻咽喉科学教室 }
\end{array}\right)
$$

